\title{
Clearance of Maedi-visna infection in a longitudinal study of naturally infected rams is associated with homozygosity for the TMEM154 resistance allele
}

\author{
Scott Jones ${ }^{1,2}$, Heather McKay ${ }^{1,3}$, Laura Eden ${ }^{1,4}$, Nicola Bollard ${ }^{1}$, Stephen Dunham¹, Peers Davies ${ }^{1,5}$ and \\ Rachael Tarlinton ${ }^{1, *}$
}

\begin{abstract}
Maedi-visna (MV) is a lentiviral disease of sheep responsible for severe production losses in affected flocks. There are no vaccination or treatment options with control reliant on test and cull strategies. The most common diagnostic methods used at present are combination ELISAs for Gag and Env proteins with virus variability making PCR diagnostics still largely an experimental tool. To assess variability in viral loads and diagnostic tests results, serology, DNA and RNA viral loads were measured in the blood of 12 naturally infected rams repeatedly blood sampled over 16 months. Six animals tested negative in one or more tests at one or more time points and would have been missed on screening programmes reliant on one test method or a single time point. In addition the one animal homozygous for the ' $\mathrm{K}$ ' allele of the TMEM154 E35K SNP maintained very low viral loads in all assays and apparently cleared infection to below detectable limits at the final time point it was sampled. This adds crucial data to the strong epidemiological evidence that this locus represents a genuine resistance marker for MV infection and is a strong candidate for selective breeding of sheep for resistance to disease.
\end{abstract}

\section{INTRODUCTION}

Small ruminant lentiviruses (SRLVs) including Maedi-visna (MV) and Caprine Arthritis-Encephalitis (CAE) are lentiviral diseases of sheep and goats respectively that have a severe economic impact on infected flocks. SRLVs infect monocytes and remain dormant until these mature into macrophages, hence it has a very long latent period with clinical signs often not developing for several years. In sheep MV is primarily a respiratory disease with affected lungs greatly enlarged and displaying typical macrophage infiltrations, though encephalitis and mastitis are also clinical syndromes associated with virus infection [1]. SRLVs in common with other lentiviruses display extreme genetic hypervariability [2] which has meant that to date the development of effective vaccines has been unsuccessful; in some cases experimental vaccines have even enhanced infection [3]. Treatment of lentiviral disease with antiretroviral drugs in sheep is generally regarded as uneconomical and control programmes for the disease primarily rely on culling affected individuals; this can be very detrimental to affected flocks with infection rates of greater than $50 \%$ in many flocks by the time clinical signs are noticed and the disease diagnosed [4].

Breed specific resistance to MV has long been recognised $[5,6]$ with increased interest in recent years in selecting for genetic resistance to the virus. Small deletions in the C-C chemokine receptor type 5 (CCR5) gene (known to convey resistance to human immunodeficiency virus) have been explored with equivocal results [7-10]. There is however increasingly strong evidence for an $\mathrm{E} / \mathrm{K}$ (glutamic acid/lysine) substitution at position 35 in exon 2 of the transmembrane protein gene TMEM154 being associated with resistance to MV in sheep. Mutations in TMEM154 (function unknown) were first identified as potential MV resistance allelles in a genome wide association study of naturally infected ewes [11, 12]. Multiple large studies of naturally infected animals

Received 05 October 2021; Accepted 04 January 2022; Published 10 February 2022

Author affiliations: 'School of Veterinary Medicine and Science, University of Nottingham, Sutton Bonington Campus, Loughborough LE12 5RD, UK; ${ }^{2}$ Department of Life Sciences, Imperial College London, London SW7 2AZ, UK; ${ }^{3}$ Three Valleys Veterinary, 107 Kesh Road, Irvinestown, Enniskillen BT94FX, UK; “Bishopton Veterinary Group, Mill Farm, Studley Road, Ripon, North Yorkshire, HG4 2QR, UK; ${ }^{5}$ Department of Livestock and One Health, University of Liverpool, Liverpool, CH64 7TE, UK.

*Correspondence: Rachael Tarlinton, rachael.tarlinton@nottingham.ac.uk

Keywords: Maedi-visna; sheep; retrovirus; TMEM154; small ruminant lentivirus.

Abbreviations: CAE, caprine arthritis-encephalitis; CAEV, caprine arthritis-encephalitis virus; CCR5, C-C chemokine receptor type 5; MV, Maedi-visna; MVV, Maedi-visna virus; SRLVs, small ruminant lentiviruses.

Sequences of the TMEM154 exon 2 (that differ from the wild type) have been submitted to ENA with the accession numbers (OU642616-0U642637). 001506 ( 2022 The Authors 
have demonstrated consistently lower infection rates in animals homozygous with the ' $K$ ' allele at this site [9, 12-16], with an estimated 2-3 fold lower risk of seropositivity for MV in affected flocks. Though resistance may be dependent on which virus strain animals are infected with, with some evidence that in animals homozygous for the ' $\mathrm{K}$ ' allele or with larger deletions in this gene are more likely to carry particular virus subtypes $[17,18]$.

The hypervariablity of the virus and the low levels of viral DNA found in the blood during the latent stage has confounded attempts to develop PCR based diagnostics that will cover all strains. Current diagnostics are usually ELISAs based on a combination of Env and Gag proteins and are greater than $90 \%$ specific and sensitive for detecting infected animals [19], they do however suffer from a long latent period between infection and sero-conversion meaning multiple screens of an affected flock are usually necessary to detect and remove all infected animals. Strain specific PCR tests can detect infection earlier than serology tests but to date remain only in experimental use [19-22].

There are few longitudinal studies of Maedi-visna virus (MVV) infected animals outside of short term experimental settings [23-26]. Most studies following the same infected animals for extended periods of time pre-date the diagnostics in use today $[27,28]$ meaning we have little idea what the variability in antibody and viral titre in affected animals is and how this may potentially confound screening programmes for the disease. To assess variability in viral load and diagnostic test results this study followed a group of twelve naturally infected rams for 16 months, testing them at two or three time points with commercially available ELISA serology tests for MV and strain specific qPCRs for DNA and RNA viral loads in the blood. The animals displayed no consistent patterns in viral load with the three tests not correlating well with each other. Six animals tested negative at one time point for one or more tests, highlighting why repeated testing with multiple tests may be necessary to identify all infected animals.

Animals were additionally genotyped for TMEM154 allelles. One animal apparently cleared the virus to below detectable limits in all tests at its final sampling point. This animal was the only one in the study homozygous for the K allele at E35K TMEM154, raising the possibility that in addition to providing resistance to initial infection animals with this allele may be better able to control virus infection.

\section{METHODS}

Five Aberfield and seven Abermax MVV seropositive rams (12 in total) were included in this study. Rams were identified as being MVV positive during routine testing (Elitest ELISA Hyphen Biomed) as part of a MV surveillance scheme (Scotland's Rural University College premium sheep health and goat scheme) after which they were acquired by the University of Nottingham in 2015 (at approximately 18 months of age). Animals were held at pasture with available shelter and supplementary rations. Five animals were culled for flock management purposes in June and July 2016 with the seven surviving rams euthanased in October 2016 (Table 1).

Table 1. Animals used in this study

\begin{tabular}{|c|c|c|}
\hline Ram ID & Breed & Date of death \\
\hline 2 & Aberfield & $28 / 10 / 16$ \\
\hline 3 & Aberfield & $28 / 10 / 16$ \\
\hline 4 & Abermax & $28 / 10 / 16$ \\
\hline 7 & Abermax & $28 / 10 / 16$ \\
\hline 9 & Aberfield & $28 / 10 / 16$ \\
\hline 10 & Aberfield & $28 / 10 / 16$ \\
\hline \multicolumn{3}{|c|}{ Rams euthanased } \\
\hline 25 & Abermax & $02 / 06 / 16$ \\
\hline 26 & Abermax & $20 / 06 / 16$ \\
\hline 27 & Abermax & $20 / 06 / 16$ \\
\hline
\end{tabular}


For detection of MVV, blood was collected from seropositive rams in April 2015, December 2015 and in October 2016 for the surviving rams. Blood was collected in $10 \mathrm{ml}$ vacutainer blood tubes taken from the jugular vein. For separation of sera from blood, samples were left at room temperature overnight to allow for clotting after which sera was removed via pipetting. Sera and blood clots were stored at $-20^{\circ} \mathrm{C}$.

Sera was tested for the presence of SRLVs specific antibodies using the MVV/CAEV p28 Antibody Screening Test ELISA (IDEXX, Netherlands) following the manufacturer's recommended protocol. Samples were run in triplicate.

DNA was extracted from blood clots or tissue samples using the Nucleospin Tissue kit (Macherey-Nagel, Hoerdt France) using the protocol for extraction of genomic and viral DNA from blood samples or tissues. A minor change of the addition of $200 \mathrm{ul}$ PBS and a sterile $5 \mathrm{~mm}$ steel bead to the blood clots for homogenization by Retsch MM300 bead mill (Qiagen) at a frequency of $25 \mathrm{~s}^{-1}$ for $2 \mathrm{~min}$ was made. DNA was stored at $-20^{\circ} \mathrm{C}$ until use.

RNA was extracted from sera isolated using the QIAamp Viral RNA Mini Kit (Qiagen, Manchester, UK) as per manufacturers protocol.

DNA and RNA quantification was performed using the NanoDrop 8000 Spectrophotometer (Thermo Fisher UK).

Reverse transcription of RNA was carried out using random hexamer primers (Thermo Scientific) and M-MLV (Promega) or AMV (NEB) reverse transcriptase (RT) as per manufacturer's protocol with cDNA stored at $-20^{\circ} \mathrm{C}$ before use. For detection of MVV sequences from extracted nucleic acids, a Sybr green based qPCR procedure was carried out with primers targeting the pol gene specific to the strain of MVV isolated from these animals (publication in preparation) Pol1F (AGGGGATGCATACTTT ACTATACCA) and Pol1R (TCTTGTGCATGGCCCTAAAT). Reaction mixtures consisted of $1 \times$ qPCRBIO SyGreen Mix Lo-ROX master mix (PCR Biosystems), $0.04 \mu \mathrm{M}$ forward and reverse primers (Sigma-Aldrich) and $1 \mu \mathrm{l}$ of test DNA or standard in a total volume of $20 \mu \mathrm{l}$. Reaction conditions consisted of a starting incubation of $95^{\circ} \mathrm{C}$ for $15 \mathrm{~min}$ followed by $45 \mathrm{cycles}$ of $95^{\circ} \mathrm{C}$ for $5 \mathrm{~s}$, $60^{\circ} \mathrm{C}$ for $30 \mathrm{~s}$ and $72^{\circ} \mathrm{C}$ for $10 \mathrm{~s}$. A melt cycle was carried out at reaction end ranging from $65-95^{\circ} \mathrm{C}$. Reactions were carried out within a CFX Connect Real-Time PCR Detection System (Biorad Laboratories). A 1:10 standard dilution series of a synthesised PCR product positive control was run with each plate. Reactions were run in duplicate.

TMEM154 genotyping was carried out by PCR and Sanger sequencing of exon two using primers from [12]: 86824 (TCCATTTC CTTTACCTAAAAGT) and 86826 (ACTGGCCCAAATTACATAAG). PCR was carried out with $1 \mu$ of DNA extracted from the lung tissue of MVV seropositive rams, used in a reaction mixture of $25 \mu \mathrm{l}$. Each reaction contained five units of Taq DNA Polymerase, $1 \times$ standard Taq (Mg-free) reaction buffer (NEB), $3 \mathrm{mM}$ magnesium chloride $(\mathrm{MgCl} 2)(\mathrm{NEB}), 0.04 \mathrm{pmol}$ of forward and reverse primers and $0.4 \mathrm{mM}$ deoxynucleotide (dNTP) solution mix (Thermo Scientific). Standard PCR cycling conditions consisted of an initial denaturation phase of $95^{\circ} \mathrm{C}$ for $5 \mathrm{~min}$ followed by 45 cycles of $95^{\circ} \mathrm{C}, 56 / 60$ and $68^{\circ} \mathrm{C}$, each for $15-60 \mathrm{~s}$. Reactions were carried out within a Thermal cycler Life ECO (Bioer Technology). Successful amplification was determined by agarose gel electrophoresis of PCR products. Products were purified for sequencing using the Nucleospin Gel and PCR clean up kit (Machery Nagel) following the manufacturers protocol for PCR clean up. Sanger sequencing was carried out by Source Bioscience (Nottingham). Sequence analysis was carried out using BioEdit v7.2 and CLC Sequence Viewer software v8.0 (Qiagen).

\section{RESULTS}

There was no clear pattern of variation in ELISA, DNA or RNA loads in the studied animals (Fig. 1, Table 2). Antibody titres, DNA and RNA loads did not rise or fall consistently with each other or consistently increase or decrease over time. DNA loads in all animals were consistently below 40000 copies per ng DNA, whereas RNA loads varied much more dramatically with one animal reaching titres of $4.44 \times 10^{10}$ copies per $\mu \mathrm{l}$ serum (Table 2). Six different animals tested negative with different assays at one or more time points in the study.

Genotyping of exon 2 of the TMEM154 gene demonstrated 8/12 animals heterozygous for the wild-type and resistant alleles at amino acid $35(\mathrm{E} / \mathrm{K}), 3 / 12$ animals homozygous for the wild-type allele (E/E) and one animal homozygous for the resistant allele (K/K) (Table 2). Sequences of the TMEM154 exon 2 (that differ from the wild-type) have been submitted to European nucleotide archive with the accession numbers (OU642616-OU642637). The animal homozygous for the resistant allele demonstrated ELISA titres consistently below the cut off for the assay and tested negative in all three assays at the last time point before its death. There was no clear change in titres for animals homozygous for the wild-type at this allele.

\section{DISCUSSION}

The results of this study demonstrate some of the confounding factors with current MV diagnostics. All studied animals had a positive serology test for MV before the study and all tested positive for the virus in PCR tests at least once during the course of this study. However six animals tested negative in one or more tests (serology or PCR) at least once. Two animals tested negative on serology and would have been missed on a single screening of the flock conducted at this time. Screening 

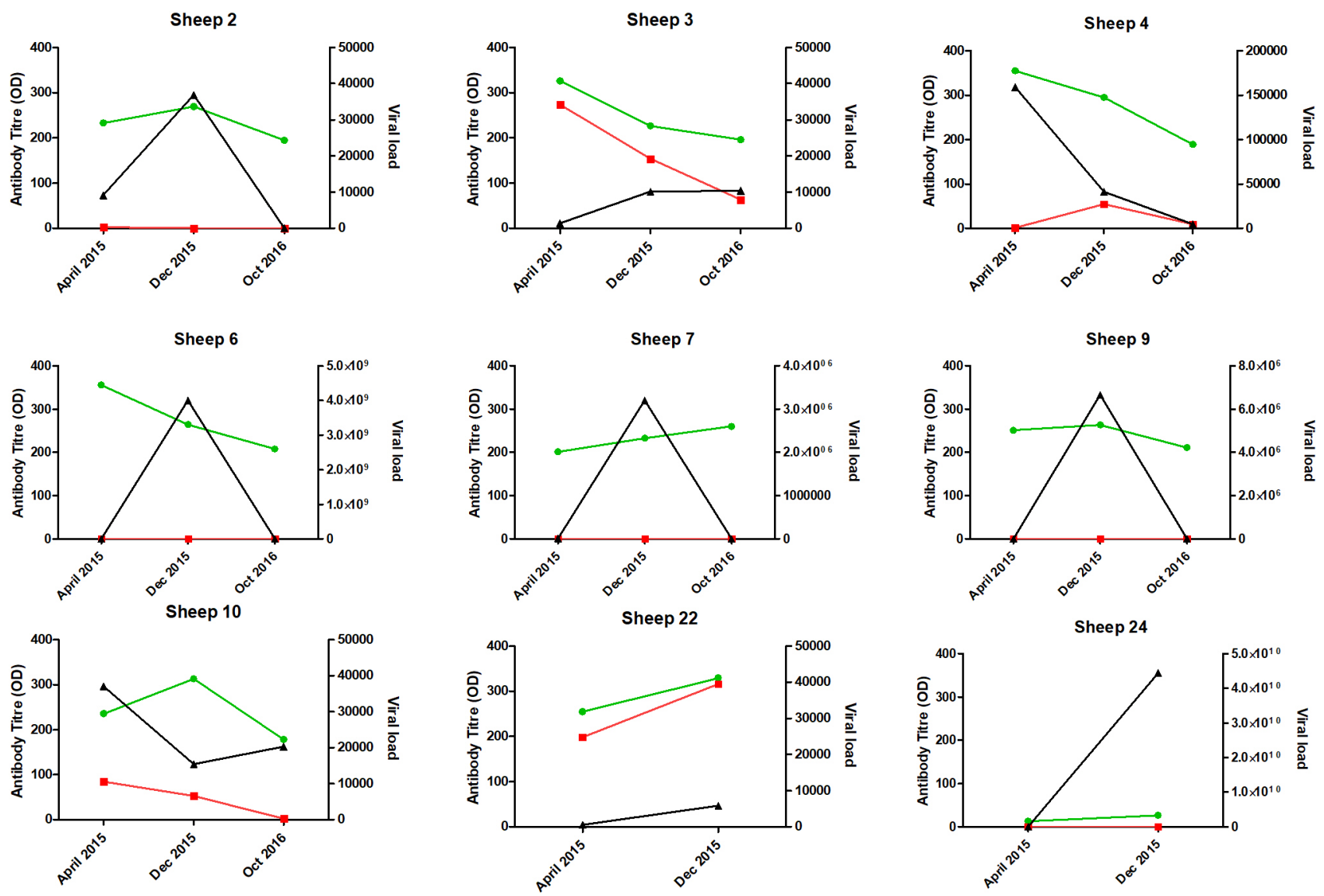

Sheep 25

Sheep 26
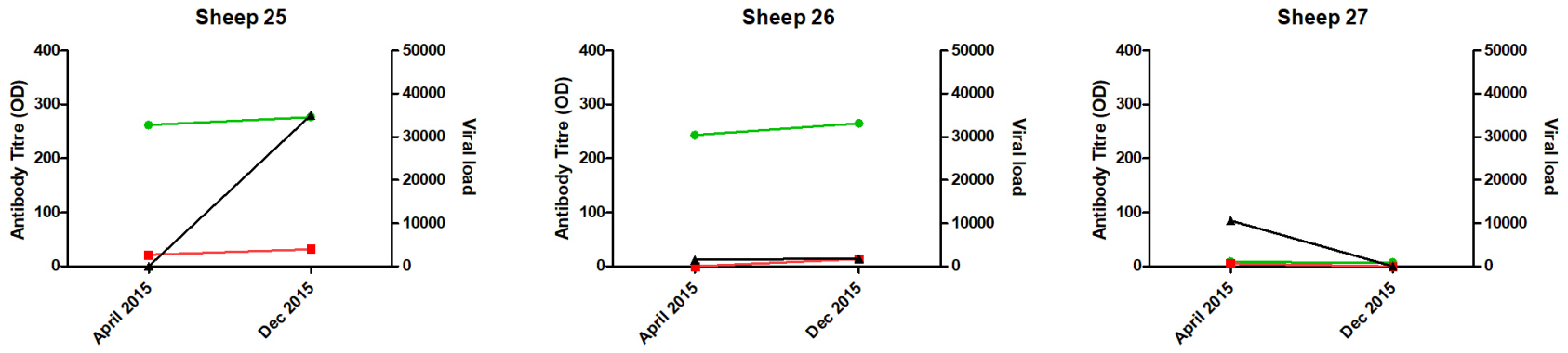

Fig. 1. Maedi-visna testing results per ram. Green line: antibody titres optical density (left axis), red line: viral DNA load ng-1 DNA (right axis), black line: viral RNA load ul ${ }^{-1}$ serum (right axis), $x$ axis: date of sample collection, sheep 22-27 have only two data points.

and control strategies for MV rely on multiple serology screens of flocks at least 6 months apart as in the UK's premium sheep health and goat schemes [29]. Multiple studies have demonstrated that the addition of PCR based blood testing to serology screening improves the rate of detection of infected animals [20,30,31], though the uptake of PCR based diagnostics for MV has been limited both by cost and the variability of the virus (making it difficult to design a PCR based test that will detect all strains) [32]. This study supports the necessity of multiple serology screening points to detect all infected animals. Although the viral RNA loads are quite variable, we consider them likely genuine rather than as a result of sequence variability as this should also have been evident in the DNA loads, which while higher than previous studies are within a much more limited range $[23,33,34]$. This may well reflect differences between proviral copies integrated into macrophage genomes and infectious viral RNA particles being released from these cells.

The other major finding of this study is that one animal homozygous for the ' $\mathrm{K}$ ' allele of TMEM154 at position 35 had a consistently low viral load in all three tests and apparently cleared the virus to below detectable limits in all assays by the final time point in the study. Extensive genetic and virus prevalence screening of MV infected flocks in multiple countries has demonstrated that sheep homozygous for the resistant allele of TMEM154 are less likely to test positive for the virus and 
Table 2. Testing results, ELISA results are optical density as per IDEXX test kit, DNA viral load ng ${ }^{-1}$ DNA, RNA viral load ul ${ }^{-1}$ serum. Negative results (zero for RNA or DNA or below assay cut off for ELISA) are shown in bold TMEM154 genotype at amino acid position 35

\begin{tabular}{|c|c|c|c|c|c|c|c|c|c|c|}
\hline \multirow[t]{2}{*}{ Ram } & \multicolumn{3}{|c|}{ April 2015} & \multicolumn{3}{|c|}{ Dec 2015} & \multicolumn{3}{|c|}{ October 2016} & \multirow{2}{*}{$\begin{array}{l}\text { TMEM154 genotype at } \\
\text { position } 35 \text { exon } 2\end{array}$} \\
\hline & ELISA & DNA & RNA & ELISA & DNA & RNA & ELISA & DNA & RNA & \\
\hline 2 & 233 & 315 & 9150 & 269 & 0 & 36900 & 195 & $\mathbf{0}$ & 0 & $\mathrm{E} / \mathrm{E}$ \\
\hline 3 & 326 & 34200 & 1400 & 227 & 19200 & 10200 & 196 & 7910 & 10400 & $\mathrm{E} / \mathrm{K}$ \\
\hline 4 & 355 & 743 & 159000 & 295 & 27400 & 41180 & 189 & 4700 & 4620 & $\mathrm{E} / \mathrm{K}$ \\
\hline 6 & 355 & 1940 & 1180 & 264 & 523 & 4000000000 & 207 & 0 & 10500 & $\mathrm{E} / \mathrm{K}$ \\
\hline 7 & 201 & 417 & 10900 & 233 & 825 & 3200000 & 260 & 0 & 2170 & $\mathrm{E} / \mathrm{K}$ \\
\hline 9 & 251 & 0 & 1180 & 263 & 1590 & 6650000 & 211 & 227 & 7100 & $\mathrm{E} / \mathrm{E}$ \\
\hline 10 & 235 & 10600 & 37000 & 313 & 6590 & 15400 & 178 & 293 & 20300 & $\mathrm{E} / \mathrm{E}$ \\
\hline 22 & 255 & 24800 & 607 & 329 & 39500 & 5840 & - & - & - & $\mathrm{E} / \mathrm{K}$ \\
\hline 24 & 13 & 3900 & 46200 & 27 & 8860 & 44400000000 & - & - & - & $\mathrm{E} / \mathrm{K}$ \\
\hline 25 & 262 & 2740 & 0 & 277 & 4020 & 35000 & - & - & - & $\mathrm{E} / \mathrm{K}$ \\
\hline 26 & 243 & 881 & 1560 & 265 & 1730 & 1800 & - & - & - & $\mathrm{E} / \mathrm{K}$ \\
\hline 27 & 9 & 693 & 10600 & 7 & 0 & 0 & - & - & - & $\mathrm{K} / \mathrm{K}$ \\
\hline
\end{tabular}

have lower viral loads $[8,9,11-13,15,16]$. While only a single animal, this study adds a crucial piece of evidence suggesting that sheep with this allele are also able to clear a previous infection to below detectable levels. Although, we cannot exclude the possibility of the animal having a very low level latent infection below the detection limits of the assay, the study still adds more evidence to the body of data that homozygosity for K at TMEM154 E35K represents a genuine genetic resistance marker for MV. Genomic selection for for genetic resistance to disease has been used successfully to virtually eradicate other infectious diseases such as scrapie in UK sheep flocks [35]. This is an attractive option for disease control in commercial sheep flocks, although possible adverse impacts on production traits should be studied for this genetic selection in follow-up studies.

Funding information

This project was funded by an Agriculture and Horticulture Development Board (AHDB) grant number 6120028011 PhD studentship awarded to P.D. and R.T.

Author contributions

S.J. performed the experimental work in the manuscript (PCR, serology, sheep blood sampling); L.E., H.M. and N.B. bled sheep; R.T. and P.D. conceived the study; R.T., P.D. and S.D. supervised work. R.T. wrote the manuscript, all authors reviewed and edited the manuscript.

Conflicts of interest

The authors declare that there are no conflicts of interest.

Ethical statement

All animal management and procedures were reviewed and approved by the Home Office under the 'Animals (Scientific Procedures) Act 1986' (Licence no. PPL 30/3367).

\section{References}

1. Larruskain A, Jugo BM. Retroviral infections in sheep and goats: small ruminant lentiviruses and host interaction. Viruses 2013;5:2043-2061.

2. Minardi da Cruz JC, Singh DK, Lamara A, Chebloune Y, et al. Small ruminant lentiviruses (SRLVs) break the species barrier to acquire new host range. Viruses 2013:5:1867-1884.

3. Torsteinsdóttir S, Carlsdóttir HM, Svansson V, Matthíasdóttir S, Martin $\mathrm{AH}$, et al. Vaccination of sheep with Maedi-visna virus gag gene and protein, beneficial or harmful? Vaccine 2007:25:6713-6720.

4. Illius AW, Lievaart-Peterson K, McNeilly TN, Savill NJ, et al. Epidemiology and control of maedi-visna virus: Curing the flock. PLoS One 2020;15:e0238781.

5. Pálsson PA. Maedi and visna in sheep. Front Biol 1976;44:17-43.
6. Cutlip RC, Lehmkuhl HD, Brogden KA, Sacks JM, et al. Breed susceptibility to ovine progressive pneumonia (maedi/visna) virus. Vet Microbiol 1986;12:283-288.

7. White SN, Mousel MR, Reynolds JO, Lewis GS, Herrmann-Hoesing LM, et al. Common promoter deletion is associated with 3.9-fold differential transcription of ovine CCR5 and reduced proviral level of ovine progressive pneumonia virus. Anim Genet 2009:40:583-589.

8. Alshanbari FA, Mousel MR, Reynolds JO, Herrmann-Hoesing LM, Highland MA, et al. Mutations in Ovis aries TMEM154 are associated with lower small ruminant lentivirus proviral concentration in one sheep flock. Anim Genet 2014:45:565-571.

9. Molaee V, Eltanany M, Lühken G. First survey on association of TMEM154 and CCR5 variants with serological maedi-visna status of sheep in German flocks. Vet Res 2018;49:36. 
10. Colussi S, Desiato R, Beltramo C, Peletto S, Modesto P, et al. A single nucleotide variant in the promoter region of the CCR5 gene increases susceptibility to arthritis encephalitis virus in goats. BMC Vet Res 2019;15:230.

11. Heaton MP, Clawson ML, Chitko-Mckown CG, Leymaster KA, Smith TPL, et al. Reduced lentivirus susceptibility in sheep with TMEM154 mutations. PLoS Genet 2012;8:e1002467

12. Heaton MP, Kalbfleisch TS, Petrik DT, Simpson B, Kijas JW, et al. Genetic testing for TMEM154 mutations associated with lentivirus susceptibility in sheep. PLoS One 2013;8:e55490.

13. Leymaster KA, Chitko-McKown CG, Clawson ML, Harhay GP, Heaton MP, et al. Effects of TMEM154 haplotypes 1 and 3 on susceptibility to ovine progressive pneumonia virus following natural exposure in sheep. J Anim Sci 2013;91:5114-5121.

14. Molaee V, Otarod V, Abdollahi D, Lühken G, et al. Susceptibility in Iranian and German sheep assessed by determination of TMEM154 E35K. Animals (Basel) 2019;9:E685.

15. Yaman Yet al. Association of tmem154 variants with visna/maedi virus infection in turkish sheep. Small Rumin Res 2016;177:61-67.

16. Arcangeli $C$, Lucarelli D, Torricelli M, Sebastiani C, Ciullo M, et al. First survey of SNPs in TMEM154, TLR9, MYD88 and CCR5 genes in sheep reared in Italy and their association with resistance to SRLVs infection. Viruses 2021;13:1290. RESOURCE\&gt;

17. Sider LH, Heaton MP, Chitko-Mckown CG, Harhay GP, Smith TPL, et al. Small ruminant lentivirus genetic subgroups associate with sheep TMEM154 genotypes. Vet Res 2013;44:64

18. Clawson ML, Redden R, Schuller G, Heaton MP, Workman A, et al. Genetic subgroup of small ruminant lentiviruses that infects sheep homozygous for TMEM154 frameshift deletion mutation A4 $\Delta 53$. Vet Res 2015;46:22

19. Michiels R, Van Mael E, Quinet C, Adjadj NR, Cay AB, et al. Comparative Analysis of Different Serological and Molecular Tests for the Detection of Small Ruminant Lentiviruses (SRLVs) in Belgian Sheep and Goats. Viruses 2018;10:E696.

20. Brinkhof JMA, Houwers DJ, Moll L, Dercksen D, van Maanen C, et al. Diagnostic performance of ELISA and PCR in identifying SRLVinfected sheep and goats using serum, plasma and milk samples and in early detection of infection in dairy flocks through bulk milk testing. Vet Microbiol 2010;142:193-198.

21. Barquero N, Arjona A, Domenech A, Toural C, de las Heras A, et al. Diagnostic performance of PCR and ELISA on blood and milk samples and serological survey for small ruminant lentiviruses in central Spain. Vet Rec 2011;168:20

22. Barquero N, Gomez-Lucia E, Arjona A, Toural C, Heras A las, et al. Evolution of specific antibodies and proviral DNA in milk of small ruminants infected by small ruminant lentivirus. Viruses 2013:5:2614-2623.

23. Rachid A, Croisé B, Russo $P$, Vignoni M, Lacerenza D, et al. Diverse host-virus interactions following caprine arthritis-encephalitis virus infection in sheep and goats. J Gen Virol 2013;94:634-642.

24. Pinczowski $P$, Sanjosé L, Gimeno M, Crespo H, Glaria I, et al. Small ruminant lentiviruses in sheep: pathology and tropism of 2 strains using the bone marrow route. Vet Pathol 2017:54:413-424.

25. Niesalla H, McNeilly TN, Ross M, Rhind SM, Harkiss GD, et al. Experimental infection of sheep with visna/maedi virus via the conjunctival space. J Gen Virol 2008;89:1329-1337.

26. Leginagoikoa I, Daltabuit-Test M, Alvarez V, Arranz J, Juste RA et al. Horizontal Maedi-Visna virus (MVV) infection in adult dairysheep raised under varying MVV-infection pressures investigated by ELISA and PCR. Res Vet Sci 2006;80:235-241.

27. Sihvonen L. Late immune responses in experimental maedi. Vet Microbiol 1984;9:205-213.

28. Larsen HJ, Hyllseth B, Krogsrud J. Experimental maedi virus infection in sheep: cellular and humoral immune response during three years following intranasal inoculation. Am J Vet Res 1982;43:384-389

29. SRUC. Premium Sheep and Goat Health schemes; 2020. https:// www.sruc.ac.uk/business-services/what-is-your-goal/veterinary-laboratory-services/sheep-and-goat-health-schemes/ premium-sheep-and-goat-health-schemes/member-resources/

30. Alvarez V, Daltabuit-Test M, Arranz J, Leginagoikoa I, Juste RA, et al. PCR detection of colostrum-associated Maedi-Visna virus (MVV) infection and relationship with ELISA-antibody status in lambs. Res Vet Sci 2006;80:226-234.

31. Gil A, Rola M, Kuźmak J. Application of PCR technique in diagnosis of small ruminant lentivirus infection in sheep and goats. Pol J Vet Sci 2006;9:213-217.

32. Kalogianni Al, Bossis I, Ekateriniadou LV, Gelasakis Al. Etiology, epizootiology and control of maedi-visna in dairy sheep: a review. Animals (Basel) 2020;10:E616.

33. Reina $R$, Barbezange $C$, Niesalla $H$, de Andrés $X$, Arnarson $H$, et al. Mucosal immunization against ovine lentivirus using PEI-DNA complexes and modified vaccinia Ankara encoding the gag and/or env genes. Vaccine 2008:26:4494-4505

34. Niesalla $H$, de Andrés $X$, Barbezange $C$, Fraisier $C$, Reina $R$, et al. Systemic DNA immunization against ovine lentivirus using particle-mediated epidermal delivery and modified vaccinia Ankara encoding the gag and/or env genes. Vaccine 2009;27:260-269.

35. Bishop SC. Genetic resistance to infections in sheep. Vet Microbiol 2015;181:2-7

\section{Five reasons to publish your next article with a Microbiology Society journal}

1. The Microbiology Society is a not-for-profit organization.

2. We offer fast and rigorous peer review - average time to first decision is 4-6 weeks.

3. Our journals have a global readership with subscriptions held in research institutions around the world.

4. $80 \%$ of our authors rate our submission process as 'excellent' or 'very good'.

5. Your article will be published on an interactive journal platform with advanced metrics

Find out more and submit your article at microbiologyresearch.org. 